\title{
Korelasi Pemecahan Masalah dan Indikator Berfikir Kritis
}

\author{
Budi Cahyono
}

\begin{abstract}
Abstrak
Didunia yang begitu cepat berubah, tingkatan berfikir kritis akan menentukan daya tahan seseorang dalam berkompetisi untuk menjadi yang terunggul. Kemampuan berfikir kritis adalah kemampuan yang penting karena dapat mengembangkan dan menyatakan ide-ide penting, membantu kita dalam mengkaji gagasan-gagasan yang rumit secara sistematis untuk dapat memahami lebih baik sehingga mencegah orangorang untuk membuat keputusan yang buruk dan membantu mereka dalam memecahkan masalah. Sementara itu, hampir setiap bidang kehidupan manusia memerlukan kemampuan pemecahan masalah. Bahkan, kesuksesan dalam kehidupan sangat ditentukan oleh kemampuannya dalam memecahkan masalah baik dalam skala besar maupun kecil. Dalam hal ini berfikir kritis menjadi syarat yang penting bagi setiap orang untuk memecahkan masalah.

Banyak pendapat para ahli tentang pengertian berfikir kritis. Secara umum berfikir kritis dapat didefinisikan suatu proses penggunaan kemampuan berpikir secara efektif yang dapat membantu seseorang untuk membuat, mengevaluasi, serta mengambil keputusan tentang apa yang diyakini atau dilakukan. Dari definisi tersebut dapat maka berpikir kritis mempunyai ciri-ciri: (1) menyelesaikan suatu masalah dengan tujuan tertentu, (2) menganalisis, menggeneralisasikan,mengorganisasikan ide berdasarkan fakta/informasi yang ada, dan (3) menarik kesimpulan dalam menyelesaikan masalah tersebut secara sistematik dengan argumen yang benar. Berfikir kritis sangat diperlukan dalam proses pembelajaran disemua mata pelajaran termasuk matematika. Dalam pembelajaran matematika kemampuan berfikir kritis akan sangat dibutuhkan dalam proses memahami konsep, menganalisa masalah dan menentukan solusi yang tepat dari sebuah permasalahan di matematika.

Hubungan antara berpikir kritis dan pemecahan masalah menarik untuk dikaji. Selama ini pemecahan masalah sering dipandang sebagai keterampilan yang bersifat mekanistis, sistematis, dan abstrak. Namun, seiring berkembangnya teori-teori belajar kognitif, pemecahan masalah lebih dipandang sebagai aktivitas mental yang kompleks yang memuat berbagai keterampilan kognitif. Dalam konteks sebagaimana diuraikan di atas, berpikir kritis dipandang sebagai syarat bagi tumbuhnya kemampuan pemecahan masalah. Namun, sebaliknya, pemecahan masalah dapat pula dipandang sebagai sarana untuk menumbuhkan kemampuan berfikir kritis. Perlu diketahui bahwa pemecahan masalah mempunyai berbagai peran, yakni sebagai kemampuan, pendekatan, dan sebagai konteks. Mengingat kemampuan berfikir kritis tidak tumbuh dalam suasana atau ruang hampa, maka ia memerlukan sarana atau konteks. Dalam hal ini, konteks dimaksud dapat berupa aktivitas pemecahan masalah. Dalam makalah ini akan dieksplorasi mengenai hubungan antara pemecahan masalah dan berpikir kritis ditinjau dari berbagai aspeknya.
\end{abstract}

Kata kunci : pemecahan masalah, berpikir kritis

\section{PENDAHULUAN}

Di dunia yang begitu cepat berubah, kemampuan berfikir kritis akan menentukan daya tahan seseorang dalam berkompetisi untuk menjadi yang terunggul karena akan meningkatkan daya kompetitif dari individu tersebut. Dengan berfikir kritis maka kemampuan individu untuk menyelesaikan masalah secara optimal akan meningkat karena akan memandang masalah dari berbagai perfektif. Cara pandang demikian memungkinkan individu tersebut memperoleh berbagai alternatif solusi yang sesuai untuk menyelesaikan masalah tersebut.

Berfikir kritis dan kemampuan pemecahan masalah merupakan kemampuan-kemampuan yang dituntut oleh dunia kerja saat ini. Menurut Career Center Maine Department of Labor (2004), beberapa karakteristik individu yang dikehendaki dunia kerja adalah: (1) mempunyai kepercayaan 
diri, (2) mempunyai motivasi untuk berprestasi, (3) menguasai keterampilan-keterampilan dasar seperti membaca, menulis, mendengarkan, berbicara, dan melek komputer (computer literacy), (4) menguasai keterampilan berpikir, seperti memecahkan masalah (problem solving), membuat soal (problem posing), berfikir kritis, mengambil keputusan (decision making), berpikir analitis (analythical thinking), dan berpikir kreatif (creative thinking), dan (5) menguasai keterampilan interpersonal, seperti kemampuan berkerja dalam tim dan melakukan negosiasi. Kreativitas dan pemecahan masalah juga menjadi kemampuan yang dituntut dunia bisnis sebagaimana dikemukakan Business in the Community/BITC (McGregor, 2007) bahwa dunia bisnis memerlukan individuindividu dengan kemampuan komunikasi baik, kemampuan bekerja dalam tim, dan kemampuan pemecahan masalah.

Demikian pentingnya kemampuan berfikir kritis dan kemampuan pemecahan masalah dalam berbagai bidang menuntut berbagai pihak, termasuk institusi pendidikan, untuk mengembangkannya. Secara eksplisit, kemampuan berpikir kritis juga menjadi salah satu standar kelulusan siswa SMP dan SMA (Depdiknas, 2006). Dikehendaki, lulusan SMP maupun SMA, mempunyai kemampuan berpikir logis, analitis, sistematis, kritis, dan kreatif, serta mempunyai kemampuan bekerja sama. Kemampuan ideal demikian diharapkan dapat dicapai melalui proses pembelajaran yang dirancang dengan baik. Menurut Park (2004), pendidikan dapat diartikan sebagai proses yang dimaksudkan untuk mengembangkan potensi siswa, termasuk potensi kreatifnya.

Sampai saat ini perhatian pengembangan kemampuan untuk berfikir kritis masih relatif rendah sehingga masih terbuka peluang untuk mengesplorasi kemampuan berfikir kritis serta pengembangannya. Dalam makalah ini akan dieksplorasi keterkaitan antara berfikir kritis dan pemecahan masalah. Hasil kajian ini dapat dijadikan dasar pada penelitian penelian berikutnya tentang berfikir kritis.

\section{TINJAUAN BERPIKIR KRITIS}

Berpikir kritis merupakan perwujudan dari berpikir tingkat tinggi (higher order thinking). Dalam bidang pendidikan (Aisyah, 2008:21), berpikir kritis didefinisikan sebagai pembentukan kemampuan aspek logika seperti kemampuan memberikan argumentasi, silogisme dan pernyataan yang proposional. Menurut Beyer (1987:33), "Berpikir kritis adalah kumpulan operasi-operasi spesifik yang mungkin dapat digunakan satu persatu atau dalam banyak kombinasi atau urutan dan setiap operasi berpikir kritis tesebut memuat analisis dan evaluasi”. Sedangkan Ennis (dalam Williawati, 2009:11) mengemukakan, "Definisi berpikir kritis adalah berpikir secara beralasan dan reflektif dengan menekankan pembuatan keputusan tentang apa yang harus dipercayai atau dilakukan”. Oleh karena itu, indikator kemampuan berpikir kritis dapat diturunkan dari aktivitas kritis siswa sebagai berikut: 
(1) Mencari pernyataan yang jelas dari setiap pertanyaan;

(2) Mencari alasan;

(3) Berusaha mengetahui informasi dengan baik;

(4) Memakai sumber yang memiliki kredibilitas dan menyebutkannya;

(5) Memperhatikan situasi dan kondisi secara keseluruhan;

(6) Berusaha tetap relevan dengan ide utama;

(7) Mengingat kepentingan yang asli dan mendasar;

(8) Mencari alternatif;

(9) Bersikap dan berpikir terbuka;

(10) Mengambil posisi ketika ada bukti yang cukup untuk melakukan sesuatu;

(11) Mencari penjelasan sebanyak mungkin apabila memungkinkan;

(12) Bersikap secara sistimatis dan teratur dengan bagian-bagian dari keseluruhan masalah.

Radiansyah (2010) mengungkapkan beberapa kemampuan yang dikaitkan dengan konsep berpikir kritis, yaitu: "Kemampuan-kemampuan untuk memahami masalah, menyeleksi informasi yang penting untuk menyelesaikan masalah, memahami asumsi-asumsi, merumuskan dan menyeleksi hipotesis yang relevan, serta menarik kesimpulan yang valid dan menentukan kevalidan dari kesimpulan-kesimpulan". Berpikir kritis adalah sebuah proses yang kompleks dan jika dilakukan dengan baik, berpikir kritis akan membantu kita dalam mengkaji gagasan-gagasan yang rumit secara sistematis untuk dapat memahami lebih baik, baik itu masalah ataupun akibat-akibat dalam mempraktekkannya (Inch et al., 2006: 5). Lebih lanjut Inch et al. mengemukakan bahwa seseorang yang berpikir secara kritis mengenai sebuah masalah tidak akan puas dengan solusi yang jelas atau nyata tetapi akan menangguhkan penilaiannya sambil mencari semua argumen, fakta-fakta, dan penalaran-penalaran yang relevan yang dapat mendukung pembuatan keputusan yang baik. (Costa, 1985: 45) mengemukakan bahwa berpikir kritis menggunakan proses berpikir dasar untuk menganalisis pendapat dan menghasilkan wawasan yang lebih bermakna.

Berbekal dengan kemampuan berpikir kritis, guru telah membantu mempersiapkan peserta didik untuk masa depannya. Syaipul (2010) menyatakan bahwa berpikir kritis mampu mempersiapkan peserta didik berpikir pada berbagai disiplin ilmu serta dapat digunakan untuk memenuhi kebutuhan intelektual dan pengembangan potensi peserta didik. Berpikir kritis adalah sebuah kemampuan yang penting karena mencegah orang-orang untuk membuat keputusan yang buruk dan membantu mereka dalam memecahkan masalah, tetapi ini bukanlah sebuah kemampuan yang mudah untuk dikembangkan atau digunakan.

Berpikir kritis menuntut waktu dan kedisiplinan, dapat mengembangkan dan menyatakan ideide penting untuk menjawab pertanyaan-pertanyaan dengan sebuah pemikiran yang kritis dan direncanakan. Hal senada diungkapkan oleh Bridget Arend (2009: 5) bahwa berpikir kritis 
mengembangkan salah satu cara berpikir secara mandiri tentang penyelesaian masalah.

Berdasarkan beberapa pengertian berpikir kritis di atas, maka dapat disimpulkan bahwa seseorang berpikir kritis dengan ciri-ciri: (1) menyelesaikan suatu masalah dengan tujuan tertentu, (2) menganalisis, menggeneralisasikan,mengorganisasikan ide berdasarkan fakta/informasi yang ada, dan (3) menarik kesimpulan dalam menyelesaikan masalah tersebut secara sistematik dengan argumen yang benar.

\section{PEMECAHAN MASALAH}

Pemecahan masalah bukan merupakan topik tersendiri melainkan menyatu dalam proses pembelajaran. Saat ini terdapat dorongan yang kuat dalam pendidikan untuk menjadikan pemecahan masalah sebagai komponen kunci dalam kurikulum pembelajaran matematika (Nakin, 2003). Tuntutan untuk menjadikan siswa mampu memecahkan masalah dengan baik telah menjadi tema sentral dalam pembelajaran matematika. Pembelajaran matematika hendaknya memuat pemecahan masalah sebagai bagian utama semua aspek aktivitasnya. Guru hendaknya memberikan kepada siswa masalah-masalah yang "kaya", masalah yang terkait dengan kehidupan

sehari-hari, dan masalah yang menantang dan memotivasi mereka. Pemecahan masalah merupakan cara efektif untuk mengeksplorasi ide-ide matematika baru.

Menurut Funke (2001), pada awal 1900-an, pemecahan masalah dipandang sebagai aktivitas yang bersifat mekanistis, sistematis, dan sering diasosiaskan dengan suatu konsep yang abstrak. Dalam konteks ini masalah yang diselesaikan adalah masalah yang mempunyai jawab tunggal yang diperoleh melalui proses yang melibatkan cara atau metode yang tunggal pula (penalaran konvegen). Sejalan dengan berkembangnya teori belajar kognitif, pemecahan masalah dipandang sebagai aktivitas mental yang melibatkan keterampilan kognitif kompleks. Hal ini juga sesuai dengan pendapat Kirkley (2003) yang menyatakan bahwa pemecahan masalah melibatkan keterampilan berpikir tingkat tinggi seperti visualiasi, asosiasi, abstraksi, manipulasi, penalaran, analisis, sintesis, dan generalisasi.

Terdapat beragam definisi pemecahan masalah. Menurut Nakin (2003), pemecahan masalah adalah proses yang melibatkan penggunaan langkah-langkah tertentu (heuristik), yang sering disebut sebagai model atau langkah-langkah pemecahan masalah, untuk menemukan solusi suatu masalah. Heuristik merupakan pedoman atau langkah-langkah umum yang digunakan untuk memandu penyelesaian masalah. Namun langkah-langkah ini tidak menjamin kesuksesan individu dalam memecahkan masalah. Sementara itu Gagne (Kirkley, 2003) mendefinisikan pemecahan masalah sebagai proses mensintesis berbagai konsep, aturan, atau rumus untuk memecahkan masalah.

Pengertian pemecahan masalah yang dikemukakan di atas mengindikasikan bahwa diperolehnya solusi suatu masalah menjadi syarat bagi proses pemecahan masalah dikatakan berhasil. 
Hal ini berbeda dengan pendapat Brownell (McIntosh, 2000) yang menyatakan bahwa suatu masalah belum dikatakan telah diselesaikan hanya karena telah diperolehnya solusi dari masalah itu. Menurutnya, suatu masalah baru benar-benar dikatakan telah diselesaikan jika individu telah memahami apa yang ia kerjakan, yakni proses pemecahan masalah dan mengetahui mengapa solusi yang telah diperoleh tersebut sesuai.

Biasanya, dalam konteks pembelajaran matematika, pemecahan masalah difungsikan sebagai tahap penerapan suatu konsep. Dalam hal ini, siswa diberikan kesempatan untuk menerapkan prinsipprinsip atau pengetahuan matematika ke dalam situasi masalah nyata. Namun demikian, aktivitas pemecahan masalah tidak harus diposisikan seperti itu. Menurut Nakin (2003), pemecahan masalah dapat pula dipandang sebagai proses pemerolehan atau pembentukan pengetahuan. Dengan kata lain, siswa belajar matematika melalui aktivitas pemecahan masalah. Dalam hal ini, masalah difungsikan sebagai pemicu bagi siswa untuk mengkonstruksi pengetahuannya. Pembelajaran demikian disebut pembelajaran berbasis masalah (problem based learning).

Menurut McIntosh (2000), pemecahan masalah mempunyai berbagai peran, yaitu (1) pemecahan masalah sebagai konteks (problem solving as a context for doing mathematics), yakni memfungsikan masalah untuk memotivasi siswa belajar matematika, (2) pemecahan masalah sebagai keterampilan (problem solving as a skill) yang merujuk pada kemampuan kognitif siswa dalam menyelesaikan suatu masalah, dan (3) pemecahan masalah sebagai seni (problem solving as a art), yakni memandang pemecahan masalah sebagai seni menemukan (art of discovery). Tujuan pembelajaran pemecahan masalah matematika dalam hal ini adalah untuk mengembangkan kemampuan untuk menjadi cakap (skillful) dan antusias (enthusiastic) dalam memcahkan masalah, menjadi pemikir yang independen yang mampu menyelesaikan masalah terbuka (open ended problem).

\section{PEMBELAJARAN MATEMATIKA DENGAN PEMECAHAN}

Pemecahan masalah mempunyai keutamaan tertentu dalam belajar matematika. Tujuan utama dari mengajar dan belajar matematika adalah untuk mengembangkan kemampuan memecahkan berbagai jenis masalah matematika yang kompleks secara luas. Stanick dan Kilpatrick (1988, dalam NCTM, 1980 ) yang pertama mengemukakan peran pemecahan masalah dalam matematika sekolah dan memberikan ilustrasi dalam berbagai topik. Banyak orang secara literatur mengatakan matematika sinonim dengan pemecahan masalah - mengerjakan soal cerita, mengkreasikan pola-pola, menginterpretasikan bentuk-bentuk, pengembangan pembentukan geometri, membuktikan teoremateorema, dan sebagainya.

NCTM (National Council of Teachers of Mathematics, 1980) merekomendasikan pemecahan masalah sebagai fokus matematika sekolah. Bahkan dikatakan pemecahan masalah adalah "jantung" 
matematika. Pembelajaran matematika harus dirancang sedemikian sehingga siswa mempunyai pengalaman matematika sebagai pemecahan masalah.

Mengapa NCTM menganggap penting pembelajaran matematika dengan pemecahan masalah ? Ada lima alasan yang dikemukakan. Pertama, pemecahan masalah sebagai bagian utama dari matematika artinya dalam matematika terdapat fakta-fakta dan subtansi dalam jumlah yang besar sehingga untuk mengurangi latihan dan untuk menghindari keterampilanketerampilan yang salah mempresentasikan matematika diperlukan pemecahan masalah. Kedua, matematika mempunyai banyak aplikasi yang sering mempresentasikan masalah-masalah penting dalam berbagai bidang. Ketiga, sebagai pembangun motivasi instrinsik dalam memecahkan masalah-masalah matematika. Keempat, pemecahan masalah sebagai kegiatan rekreasi. Kelima, untuk mengembangkan seni pemecahan masalah.

Dalam kegiatan untuk memecahan masalah banyak pendapat yang dikemukakan para ahli, salah satunya seperti yang dikemukakan Polya. Polya (1973) mendefinisikan pemecahan masalah sebagai usaha untuk mencari jalan keluar dari suatu kesulitan, mencapai suatu tujuan yang tidak segera dapat dicapai. Menurut Polya ada empat langkah dalam pemecahan masalah, yaitu :

(1) Memahami masalah

Dalam tahap ini, masalah harus benar-benar dipahami, seperti mengetahui apa yang tidak diketahui, apa yang sudah diketahui, apakah kondisi yang ada cukup atau tidak cukup untuk menentukan yang tidak diketahui, adakah yang berlebih-lebihan atau adakah yang bertentangan, menentukan suatu gambaran masalah, menggunakan notasi yang sesuai.

(2) Membuat rencana pemecahan masalah

Mencari hubungan antara informasi yang ada dengan yang tidak diketahui. Dalam membuat rencana ini seseorang dapat dibantu dengan memperhatikan masalah yang dapat membantu jika suatu hubungan tidak segera dapat diketahui sehingga akhirnya diperoleh suatu rencana dari pemecahan.

(3) Melaksanakan rencana

Pada tahap ini rencana dilaksanakan, periksa setiap langkah sehingga dapat diketahui bahwa setiap langkah itu benar dan dapat membuktikan setiap langkah benar.

(4) Memeriksa kembali pemecahan yang telah didapatkan

Pada tahap ini dapat diajukan pertanyaan seperti : dapatkah memeriksa hasil, dapatkah memeriksa alasan yang dikemukakan, apakah diperoleh hasil yang berbeda, dapatkah melihat sekilas pemecahannya, dapatkah menggunakan pemecahan yang telah diperoleh atau metode yang sudah digunakan untuk masalah lain yang sama. 
Sedangkan beberapa srategi yang dapat dilakukan dalam pemecahan masalah adalah sebagai berikut (Krismanto, 2003):

1. Membuat Diagram

2. Mencobakan pada soal yang lebih sederhana

3. Membuat tabel

4. Menemukan pola

5. Memecah tujuan

6. Memperhitungkan setiap kemungkinan

7. Berpikir logis

8. Bergerak dari belakang

9. Mengabaikan hal yang tidak mungkin

10. Mencoba-coba

Pembelajaran matematika dengan pemecahan masalah sebagai suatu metode pembelajaran dapat digunakan untuk melengkapi pengajaran fakta-fakta dasar, konsep-konsep, dan prosedur-prosedur. Pembelajaran matematika dengan pemecahan masalah dimulai dengan pengajuan masalah kepada siswa dan siswa diminta untuk menyelesaikannya. Untuk tingkat awal masalah yang diberikan dimulai dari masalah yang dikenal siswa dan dekat dengan lingkungan siswa. Masalah yang diberikan harus berada pada "Zone of proximal development (ZPD)" siswa, sehingga masalah tidak terlalu sulit bagi siswa dan siswa tidak frustasi untuk menyelesaikannya. Selama dalam kegiatan pemecahan masalah guru sebaiknya tidak terlalu mengarahkan siswa dan hanya membantu dengan memberikan petunjuk-petunjuk yang tidak terlalu mengarahkan siswa. Dalam menyelesaikan masalah siswa dapat bekerja secara individu atau berkelompok.

\section{BERPIKIR KRITIS DAN PENYELESAIAN MASALAH}

Wayne A. Wickelgren (1974: 15) menyatakan bahwa bagian dari masalah dapat diubah hanya dengan mengaplikasikan sebuah operasi kesatu atau lebih pernyataan untuk menghasilkan pernyataan yang baru. Pemecahan masalah adalah proses penerimaan masalah sebagai tantangan untuk menyelesaikannya. Huitt (1992) mengklasifikasikan teknik yang digunakan dalam pemecahan masalah dan pengambilan keputusan kedalam dua kelompok secara kasar, terkait dengan dikotomi kritikal/kreativitas. Kelompok pertama cenderung lebih linear dan serial, lebih terstruktur, lebih rasional dan analitik, dan lebih berorientasi ketujuan; teknik ini sering dipandang sebagai bagian dari latihan berpikir kritis. Kelompok kedua cenderung lebih holistik dan paralel, lebih emosional dan intuitif, lebih kreatif, dan lebih aktual/kinestetik; teknik ini sering dipandang sebagai bagian dari latihan berpikir kreatif. 
Polya (1957) dalam Daniel Muijs (2003: 187), Erman Suherman (2003: 91) dan Wayne A. Wickelgren (1974: 16) menawarkan suatu strategi untuk memecahkan masalah yang terdiri dari 4 langkah yaitu: (a) memahami masalah, (b) membuat rencana, (c) melaksanakan rencana, (d) melihat kembali. Memahami masalah adalah menemukan dengan tepat apa masalahnya. Ini melibatkan tindakan menemukan informasi yang relevan dengan masalah itu dan memisahkan elemen yang tidak relevan. Setelah mahasiswa dapat memahami masalahnya dengan benar, selanjutnya mereka harus mampu menyusun rencana penyelesaian masalah. Kemampuan fase kedua ini sangat bergantung pada pengalaman mahasiswa dalam menyelesaikan masalah. Membuat rencana atau merencanakan solusinya berkaitan dengan strategi umum untuk mengatasi masalah yang sering disebut sebagai strategi heuristik. Misalnya dengan memecahkan masalah menjadi sejumlah langkah kecil dan kemudian menemukan cara untuk melaksanakan langkah-langkah tersebut.

Bagian ketiga berkaitan dengan upaya menemukan solusi aktual untuk masalahnya. Pada strategi heuristik, maka kita telah melahirkan rencana yang tepat dalam kaitannya dengan algoritma mana yang akan digunakan. Langkah ini bersifat langsung dan hanya melibatkan penerapan algoritma yang dipilih saja. Langkah terakhir berkaitan dengan evaluasi hasil, yaitu memeriksa jawabannya. Pemeriksaan diketahui oleh umum tetapi sering dilupakan oleh peserta didik. Berdasarkan beberapa pengertian di atas, dapat disimpulkan bahwa penyelesaian masalah dalam matematika adalah suatu aktivitas untuk mencari solusi dari masalah matematika yang dihadapi dengan menggunakan secara integratif semua bekal pengetahuan matematika yang sudah dimiliki.

Selanjunya dapat berdasarkan beberapa pengertian berpikir kritis di atas, maka dapat disimpulkan bahwa seseorang berpikir kritis dengan ciri-ciri: (1) menyelesaikan suatu masalah dengan tujuan tertentu, (2) menganalisis, menggeneralisasikan,mengorganisasikan ide berdasarkan fakta/informasi yang ada, dan (3) menarik kesimpulan dalam menyelesaikan masalah tersebut secara sistematik dengan argumen yang benar. Dalam penelitian ini, dilakukan analisis penjenjangan berpikir kritis mahasiswa dengan menelusuri kemampuan berpikir kritis mahasiswa yang terintegrasi dalam penyelesaian masalah matematika yang melibatkan siswa secara aktif dan mengkaitkan dengan indikator-indikator kemampuan berpikir kritis. Adapun indikator-indikator dari setiap komponen berpikir kritis dapat disajikan seperti dalam diagram 1. 
Indikator berpikir kritis

Mengidentifikasi fakta-fakta yang
diberikan dengan jelas dan logis
merumuskan pokok-pokok
permasalahan dengan cermat
menerapkan metode yang pernah
dipelajari dengan akurat
$\begin{aligned} & \text { mengungkap data/definisi/ teorema } \\ & \text { dalam menyelesaikan masalah dengan } \\ & \text { tonnt } \\ & \text { memutuskan dan melaksanakan dengan } \\ & \text { benar }\end{aligned}$
$\begin{aligned} & \text { mengevaluasi argumen yang relevan } \\ & \text { dalam penyelesaian suatu masalah } \\ & \text { dengan teliti }\end{aligned}$
$\begin{aligned} & \text { membedakan antara kesimpulan yang } \\ & \text { didasarkan pada logika yang valid / } \\ & \text { tidak valid. }\end{aligned}$

\section{PENUTUP}

Berpikir Kritis dan pemecahan masalah sangat berkaitan erat. Kemampuan pemecahan masalah mempersyaratkan kemampuan berpikir kritis dalam mengeksplorasi berbagai alternatif cara atau solusi. Sementara sebaliknya aktivivitas pemecahan masalah menyediakan situasi problematik yang menjadi pemicu (trigger) berkembangnya potensi berfikir kritis siswa. Keterkaitan demikian perlu dieksplorasi sebagai dasar untuk mengembangkan kedua kemampuan tersebut. dari kemampuan pemecahan masalah peserta didik dapat dijadikan sebagai indikator kemampuan berfikir kritisnya. 


\section{DAFTAR PUSTAKA}

Arend, Bridget. 2009. Encouraging critical thinking in online threaded discussions. The Journal of Educators Online, 6/1: 1-23.

Costa. A. L. (1985). Developing Mind: A Resource Book for Teaching Thinking (ed). Alexandria: ASDC.

Daniel Muijs dan David Reynolds. 2003. Effective Teaching. Yogyakarta: Pustaka Belajar.

Erman Suherman, dkk. 2003. Stategi Pembelajaran Matematika Kontemporer. Universitas Pendidikan Indonesia.

Facione, P. A. 2009. Critical Thinking: What It is and Why It Counts. InsightAssessment, (Online), (http://www.insightassessment.com, diakses 17 Juni 2009).

Funke, J. (2001). Thinking \& Problem Solving. [Online]. Tersedia:http://www.psychology.uniheidelberg.de/AE/allg/. [5 April 2008]

Huitt. W. 1992. Problem solving and decision making: Consideration of individual differences using the Myers-Briggs Type Indicator. Journal of Psychological Type,24,33-44.tersedia dalam: http://chiron.valdosta.edu/whuitt/papers/prbsmbti.html. diakses 10 Juli 2010.

Hwang, Wu-Yuin, Chen, Nian-Shing, Dung, Jian-Jie, dan Yang, Yi-Lun. (2007).Multiple Representation Skills and Creativity Effects on Mathematical Problem Solving using a Multimedia Whiteboard System. International Forum of Educational Technology \& Society Journals. ISSN 1436-4522. [Online].Tersedia: http://www.ifets.info/abstrack.php. [7 September 2007].

Kirkley, J. (2003). Principles for Teaching Problem Solving. Plato Learning Center. [Online]. Tersedia: http://www.plato.com/downloads/papers/paper_04.pdf. [9Mei 2008].

Nakin, J. B. N. (2003). Ceativity and Divergent Thinking in Geometry Education. Disertasi University of South Africa. [Online]. Tersedia: http://etd.unisa.ac.za/ETD- b/theses/available/etd-04292005151805/unrestricted/00thesis.pdf. [7 Januari 2008].

Park, H.. (2004). The Effects of Divergent Production Activities with Math Inquiry and Think Aloud of Students With Math Difficulty. Disertasi. [Online] Tersedia: http://txspace.tamu.edu/bitstream/1969.1/2228/1/etd-tamu-2004. [15 November 2007]

Polya, G. 1973. How to Solve It (New of Mathematical Method). Second Edition. New Jersey: Prence University Press.

Rasiman, dkk. 2011. Penjenjangan Berpikir Kritis Siswa SMA Kelas RSBI dan Reguler dalam Menyelesaikan Masalah Matematika Ditinjau dari Perbedaan Kemampuan Matematika. Laporan penelitian: IKIP PGRI Semarang. 